\title{
Anticonvulsant Activity of Apasmarari rasa - An Experimental Study
}

\author{
Research Article
}

\author{
Vikas Saroch $^{1^{*}}$, Hiremath $\mathbf{R S}^{2}$, Patil PA $^{3}$ \\ 1*. PG Scholar 2. Asst. Professor, \\ KLEU's Shri BMK AM and Research Centre Belgaum, Karnataka. \\ 3.Professor, Department of Pharmacology. KLEU'S Dental College Bangalore,Karnataka.
}

\begin{abstract}
Apasmarari rasa, a unique Ayurvedic preparation having hingulottha shuddha parad (HSP), Shuddha Gandhaka (SG) and Shuddha Tuttha (ST) and Bhavana dravya (Trituration) as Tinospora cordifolia (Guduchi) as ingredients. The pharmaceutical processing involved preparation of chakrikas (pellets) by triturating the ingredients and sealing them in Sharava (shallow earthen disc) samputa (uniform smeared and dried) and subjecting the apparatus to Agni. After self-cooling (swangasheeta), the mixture was triturated with kadali kanda swarasa for one day and the final product was subjected to analysis.

Apasmarari rasa was subjected to assess the LD 50 and Anti convulsant activity on Male Albino rats was by means of MES (Maximal Electro convulsing Shock) Method. A supra maximal strength was $150 \mathrm{~mA}$ in rats for 0.2 seconds and stimulus was applied via ear clip electrodes. The animal dose of Phenytoin $(7.2 \mathrm{mg} / \mathrm{kg})$, Smriti sagar rasa $(18 \mathrm{mg} / \mathrm{kg})$ and Apasmarari rasa $(5.4 \mathrm{mg} / \mathrm{kg})$ was given orally to different groups. The animals were observed for a period of 180 minutes after being subjected to electro convulsions. Experimental study had shown some significant result when compared to other drugs. No doubt, that both standard drugs also shown good results when it comes to HLE (hind limb extension), but other factors such as time duration of flexion, tonus, clonus, recovery time amongst others in test drug group (Apasmarari rasa) showed significantly better results. Some other observation such as nasal bleeding and orbital bleeding was also absent in test drug group (Apasmarari rasa).
\end{abstract}

Keywords: Apasmarari rasa, LD 50, Anti convulsant activity, MES Method.

\section{Introduction}

Epilepsy is a major neurological disorder and up to $5 \%$ of the world population develops epilepsy in their lifetime. As per the present impact of epileptic seizures, it affects nearly 1-5\% of population (1). The current therapy of epilepsy with modern antiepileptic

*Corresponding Author:

Vikas Saroch

PG Scholar, Dept of Rasasastra,

KLEU's Shri BMK AM and Research

Centre

Belgaum, Karnataka

E-mail: dr.vsaroch@gmail.com drugs is associated with side effects, doserelated and chronic toxicity, as well as teratogenic effects, and approximately $30 \%$ of the patients continue to have seizures with current antiepileptic drugs therapy (2-4). Epileptic seizures have been known to represent an occasional discharge in the nervous tissue (5), characterized by recurrent paroxysmal changes in the neurological function caused by abnormalities in the electrical activity of the brain. Traditional systems of medicine are popular in developing countries and up to $80 \%$ of the population relies on traditional medicines or folk remedies for their primary health 
care need. Even herbs used for the treatment of epilepsy (i.e. Carissa carandas Linn.) in different systems of traditional medicine have shown activity when tested in modern bioassays for the detection of anticonvulsant activity.(6) But as Rasaaushadhis are consider to be more persuasive and as it is the need of hour for their endorsements so Apasmarari rasa chosen for this experimental study.

Apasmarari Rasa (7) (ARR) is one among those formulations which is exclusively indicated in Apasmara as explained in Rasakamdhenu (mayoortuttha rasagandho yoryut guduchika toya vimerditam driddham), having minimum ingredients like hingulottha shuddha parad (processed mercury), shudha gandhaka(processed sulphur) and shudha tuttha (processed copper sulphate), and bhavana (Trituration) dravya's like Tinnospora cordifolia (Willd.) Miers. (Guduchi) and Musa paradisiaca linn (kadali kanda swarasa) tuber juice.

Based on the above information, the present study was designed to consider the effect of Apasmarari rasa as an anti convulsant drug, on a well -established MES animal model of convulsion preceded by LD 50 determination.
Induction of maximal electroshock seizures (MES), using an electro convulse meter (ECM), is a commonly used model for evaluation of anticonvulsant drugs (8).

\section{Material and Methods: Animals:}

Adult male albino rats weighing between 150-200gms were used in the study. Initially, they were maintained on rat pallet diet and tap water (unless mentioned otherwise) at a 12 hour light dark schedule. They were group housed at a temperature of $25 \pm 10 \mathrm{C}$. Animals were randomly selected, marked to permit individual identification and kept in their cages for one week prior to dosing to allow for acclimation to the laboratory condition. DETERMINATION OF LD 50 (TEST COMPOUND) (9) - Fixed dose method (OECD guideline No. 420 of CPCSEA).

The test substance is orally administered in a single dose by using a stomach tube. Animals were fasted for $24 \mathrm{hrs}$ prior to dosing. And observation is made for 24 hours.

TEST PROCEDURE WITH STARTING DOSE OF 2000MG/KG BODY WEIGHT

TABLE-01: Showing dose schedule for LD 50 Determination (Apasmarari rasa)

\begin{tabular}{|l|l|l|l|}
\hline GROUP & DOSE & $\begin{array}{l}\text { ROUTE OF } \\
\text { ADMINISTRATION }\end{array}$ & OBSERVATION \\
\hline $\mathrm{LD}-50$ & $2000 \mathrm{mg} / \mathrm{kg}$ & Orally & $24 \mathrm{hrs}$ \\
\hline $\mathrm{LD}-50$ & $2000 \mathrm{mg} / \mathrm{kg}$ & Orally & $24 \mathrm{hrs}$ \\
\hline $\mathrm{LD}-50$ & $2000 \mathrm{mg} / \mathrm{kg}$ & Orally & $24 \mathrm{hrs}$ \\
\hline
\end{tabular}

Screening of Anti Epileptic Activity(10): MES Method:

An electrical stimulus of sufficient intensity to induce maximal seizure is applied by means of an external device stimulator or convulsiometer. A supra maximal strength is $150 \mathrm{~mA}$ in rats for 0.2 seconds is used .The stimulus is applied via corneal or ear clip electrodes. MES seizures remain the primary screening for potential Antiepileptic activity.
Requirement:

Animals - Healthy Male Wister Albino Rats (150-200 mg)

Drugs - Phenytoin (300mg/ kg) (11) and Smritisagar rasa (12) $(1000 \mathrm{mg} / \mathrm{kg})$ Test Drugs - Apasmarari rasa $(300 \mathrm{mg} / \mathrm{kg})$

Equipments-Electro-convulsiometer, Corneal or Ear Electrodes (apply $150 \mathrm{~mA}$ current for $0.2 \mathrm{sec}$ )

Preparation of doses /vehicle: 
The Drug was in powder form so triturated with distilled water.

Administration of doses:

The test substance is orally administered in a single dose by using a stomach tube. Animals were fasted overnight prior to dosing.

\section{Procedure}

1. Weigh and number the animals. Divide them into four groups each consisting of 6 rat's first group is used as control and second for drug phenytoin as a standard (A) and third group as Ayurvedic standard drug (B) i.e. Samritisagar rasa to be given, and for fourth test drug Apasmarari rasa should be given respectively.
2. Hold the animal properly, place corneal or ear electrodes on the cornea or ear pinna and apply the prescribed current, note different stages of convulsion i.e. A) Tonic flexion B) Tonic extensor phase C) Clonic convulsions D) Stupor E) recovery or death. Note the time in seconds spent by the animal in each phase of the convulsions. Repeat with other animals of control group.

3. Administer Phenytoin, Samritisagar rasa and Apasmarari rasa orally to different groups. Wait for 180 min and subject the animals to electro convulsions as described earlier.

Note the reduction in time or abolition of tonic extensor of MES convulsions

TABLE NO.02: Showing dose schedule for all groups

\begin{tabular}{|l|l|l|l|l|l|}
\hline GROUP & DRUG & $\begin{array}{l}\text { NO. OF } \\
\text { RATS }\end{array}$ & DOSE & $\begin{array}{l}\text { ROUTE OF } \\
\text { ADMIN. }\end{array}$ & $\begin{array}{l}\text { TIME OF } \\
\text { ADMINI.* }\end{array}$ \\
\hline Control & DW** & 06 & $1.5 \mathrm{ml} / \mathrm{rat}$ & Orally & $180 \mathrm{~min}$ \\
\hline SD $(\mathrm{A})$ & Phenytoin & 06 & $7.2 \mathrm{mg} / \mathrm{kg}$ & Orally & $180 \mathrm{~min}$ \\
\hline SD (B) & $\begin{array}{l}\text { Samritisagar } \\
\text { rasa }\end{array}$ & 06 & $18 \mathrm{mg} / \mathrm{kg}$ & Orally & $180 \mathrm{~min}$ \\
\hline Test & $\begin{array}{l}\text { Apasmarari } \\
\text { Rasa }\end{array}$ & 06 & $5.4 \mathrm{mg} / \mathrm{kg}$ & Orally & $180 \mathrm{~min}$ \\
\hline
\end{tabular}

* Prior To Induce MES, ** Distilled Water

STATISTICALS STUDY METHOD (13)

Fishers Exact Test:

TABLE NO.03: Showing Effect of therapeutic dose of Apasmarari rasa and its anti convulsant effect with other therapeutic equivalent drugs on MES

\begin{tabular}{|l|l|l|l|l|l|}
\hline SR. NO & DRUG/DOSE & +VE & -VE & \% & P VALUE \\
\hline 1 & $\begin{array}{l}\text { Apasmarari } \\
\text { rasa }\end{array}$ & 2 & 4 & 66.6 & $>0.22$ \\
\hline 2 & $\begin{array}{l}\text { Smritisagar } \\
\text { rasa }\end{array}$ & 2 & 4 & 66.6 & $>0.22$ \\
\hline 3 & Control & 5 & 1 & 16.6 & $<0.0075$ \\
\hline 4 & Phenytoin & 0 & 6 & 100 & $>1$ \\
\hline
\end{tabular}

- $\quad$ Control group failed to provide significant protection.

- P> 0.05 denotes insignificant difference as compare to Apasmarari rasa (anticonvulsant dose group) 
TABLE NO.04: Master Chart Showing duration of all the stages in seconds

\begin{tabular}{|c|c|c|c|c|c|c|}
\hline Group/Dose & Sl.No & Flexion & Extension & Clonus & Stupor & $\begin{array}{l}\text { Recovery } \\
\text { time }\end{array}$ \\
\hline \multirow[t]{2}{*}{ Control. } & $1 \mathrm{H}$ & $4 \mathrm{sec}$ & $8 \mathrm{sec}$ & $0 \mathrm{sec}$ & $120 \mathrm{sec}$ & $130 \mathrm{sec}$ \\
\hline & $2 \mathrm{~N}$ & $3 \mathrm{sec}$ & $11 \mathrm{sec}$ & Absent & $149 \mathrm{sec}$ & $165 \mathrm{sec}$ \\
\hline \multirow[t]{4}{*}{$1.5 \mathrm{ml} / 200 \mathrm{gm}$} & $3 \mathrm{~B}$ & $1 \mathrm{sec}$ & $12 \mathrm{sec}$ & $0 \mathrm{sec}$ & $200 \mathrm{sec}$ & $207 \mathrm{sec}$ \\
\hline & $4 \mathrm{~T}$ & $3 \mathrm{sec}$ & $12 \mathrm{sec}$ & $66 \mathrm{sec}$ & $430 \mathrm{sec}$ & $301 \mathrm{sec}$ \\
\hline & $5 \mathrm{~L}$ & $2 \mathrm{sec}$ & Absent & $95 \mathrm{sec}$ & $145 \mathrm{sec}$ & $129 \mathrm{sec}$ \\
\hline & 6UM & $2 \mathrm{sec}$ & $7 \mathrm{sec}$ & $0 \mathrm{sec}$ & $120 \mathrm{sec}$ & $129 \mathrm{sec}$ \\
\hline \multirow{6}{*}{$\begin{array}{l}\text { Phenytoin. } \\
7.2 \mathrm{mg} / 200 \mathrm{gm}\end{array}$} & $1 \mathrm{H}$ & $12 \mathrm{sec}$ & Absent & $0 \mathrm{sec}$ & $144 \mathrm{sec}$ & $156 \mathrm{sec}$ \\
\hline & $2 \mathrm{~N}$ & $4 \mathrm{sec}$ & Absent & $16 \mathrm{sec}$ & $122 \mathrm{sec}$ & $142 \mathrm{sec}$ \\
\hline & $3 \mathrm{~B}$ & $3 \mathrm{sec}$ & Absent & $0 \mathrm{sec}$ & $155 \mathrm{sec}$ & $158 \mathrm{sec}$ \\
\hline & $4 \mathrm{~T}$ & $7 \mathrm{sec}$ & Absent & $0 \mathrm{sec}$ & $147 \mathrm{sec}$ & $154 \mathrm{sec}$ \\
\hline & $5 \mathrm{~L}$ & $14 \mathrm{sec}$ & Absent & $24 \mathrm{sec}$ & $66 \mathrm{sec}$ & $104 \mathrm{sec}$ \\
\hline & 6UM & \multicolumn{5}{|c|}{ All stages are absent } \\
\hline \multirow{6}{*}{$\begin{array}{l}\text { Smritisagar } \\
\text { Rasa. } \\
18 \mathrm{mg} / 200 \mathrm{gm}\end{array}$} & $1 \mathrm{H}$ & $4 \mathrm{sec}$ & Absent & $20 \mathrm{sec}$ & $330 \mathrm{sec}$ & $624 \mathrm{sec}$ \\
\hline & $2 \mathrm{~N}$ & $3 \mathrm{sec}$ & Absent & $00 \mathrm{sec}$ & $158 \mathrm{sec}$ & $161 \mathrm{sec}$ \\
\hline & $3 \mathrm{~B}$ & $1 \mathrm{sec}$ & Absent & $10 \mathrm{sec}$ & $158 \mathrm{sec}$ & $169 \mathrm{sec}$ \\
\hline & $4 \mathrm{~T}$ & $3 \mathrm{sec}$ & $9 \mathrm{sec}$ & $8 \mathrm{sec}$ & $62 \mathrm{sec}$ & $82 \mathrm{sec}$ \\
\hline & $5 \mathrm{~L}$ & $9 \mathrm{sec}$ & Absent & $1.29 \mathrm{sec}$ & $98 \mathrm{sec}$ & $196 \mathrm{sec}$ \\
\hline & 6UM & $2 \mathrm{sec}$ & $15 \mathrm{sec}$ & $8 \mathrm{sec}$ & $123 \mathrm{sec}$ & $148 \mathrm{sec}$ \\
\hline \multirow{6}{*}{$\begin{array}{l}\text { Apasmarari } \\
\text { Rasa. } \\
5.4 \mathrm{mg} / 200 \mathrm{gm}\end{array}$} & $1 \mathrm{H}$ & $10 \mathrm{sec}$ & $3 \mathrm{sec}$ & $36 \mathrm{sec}$ & $173 \mathrm{sec}$ & $222 \mathrm{sec}$ \\
\hline & $2 \mathrm{~N}$ & \multicolumn{5}{|c|}{ All stages are absent } \\
\hline & $3 \mathrm{~B}$ & \multicolumn{5}{|c|}{ All stages are absent } \\
\hline & $4 \mathrm{~T}$ & $4 \mathrm{sec}$ & $4 \mathrm{sec}$ & $13 \mathrm{sec}$ & $147 \mathrm{sec}$ & $168 \mathrm{sec}$ \\
\hline & $5 \mathrm{~L}$ & $13 \mathrm{sec}$ & Absent & $8 \mathrm{sec}$ & $68 \mathrm{sec}$ & $89 \mathrm{sec}$ \\
\hline & 6UM & $00 \mathrm{sec}$ & Absent & $00 \mathrm{sec}$ & $00 \mathrm{sec}$ & $00 \mathrm{sec}$ \\
\hline
\end{tabular}

\section{Discussion}

Study showed some significant results in test drug when compared to other two standards. No doubt, that both standard drug also shown good results when it comes to HLE (hind limb extension), but if we consider other factors such as time duration of flexion, tonus, clonus, recovery etc. in test drug group these all factors shown better results. Some other observation such as nasal bleeding and orbital bleeding was also absent in test drug group. Abolition of Hind limb Extension, and fast recovery was an experimental observation.

\section{Conclusion}

Animal study of Apasmarari Rasa has shown some significant result when compared to other drugs like Phenytoin and Samritisagar rasa. Here one of the main criteria was HLE (Hind Limb Extension) and other factors we found that recovery period and other different stages shown better results with Apasmarari rasa. On the basis of the present results and available reports, it can be concluded that the anti- convulsion activity elucidated by Apasmarari Rasa possesses significant consequence in animals.

\section{References:}

1. Sander JWAS, Shorvon SD. Epidemiology of epilepsies. J Neurol Neurosurg Psychiatry, 1996;61: 43343.

2. Smith MC, Bleck TP. Convulsive Disorders - Toxicity of 
anticonvulsants.

Clinical

Neuropharmacol, 1991; 14,97-115.

3. Mattson RH. Efficacy and adverse effects of established and new antiepileptic drugs. Epilepsia, 1995;36 (2), S13-26.

4. Samrjn EB, Van Duijn CM , Koch S, Hiidesmaa VK, Klepel H, Bardy AH, Mannagetta GB et all Maternal use of antiepileptic drugs and the risk of major congenital malformations a joint European prospective study of human teratogenesis associated with material epilepsy .Epilepsia, $1997 ; 38,981$.

5. Theodore WR and Leonard SS, Goodman, Gilimans. Pharmacological basis of therapeutics, 8th ed .New York: Macmillan: 1991.436.

6. Karunakar Hegde, Shalin P Thakker, Arun B Joshi, CS Shastry, KS Chandrashekhar. Anticonvulsant Activity of Carissa carandas Linn. Root Extract in Experimental Mice. Tropical Journal of Pharmaceutical Research, April 2009; 8 (2): 117-25

7. Mishra Gulraj Sharma, commented by Mishra Chudamani Rasa kamdhenu , 2nd ed. Varanasi: Chaukhambha Orientalia ;1999.157p.

8. Swinyard EA, Brown WC, Goodman LS. Comparative assays of antiepileptic drugs in mice and rats. $\mathbf{J}$ Pharmacol Exp Ther 1952; 106,31930.

9. http://www.oecdlibrary.org/docserver/ download/fulltext/9742001e.pdf

10. Robert.A.Turner.Screening methods in Pharmacology.Vol 1st .2nd ed. Newyork : Academy press; 1965. 16667p.

11.Tripati.K.D. Essentials of Medical Pharmacology, 4th ed. New Delhi: Jaypee Brothers Medical publishers; 2004.383-86p.

12. Anonymous. The Ayurvedic Formulary of India, Vol. 2nd .New Delhi: Govt. of India, Ministry of Health and Family welfare; 2000.16:64. 293p.

13.P.Armitage,Statical Methods In Medical Research ,1st ed. Oxford :Blackwell Scientific Publication; 1977.IV .135-38p. 